\title{
Successes and pitfalls of chronic peritoneal dialysis in infants - a Polish nationwide outcome study
}

\author{
Anna Jander ${ }^{1}$, Irena Makulska², Joanna Latoszyńska³, Hanna Boguszewska-Bączkowska³, \\ Irena Bałasz-Chmielewska ${ }^{4}$, Ilona Zagożdżon ${ }^{4}$, Iga Załuska-Leśniewska ${ }^{4}$, Ewa Stefaniak ${ }^{5}$, \\ Beata Leszczyńska ${ }^{6}$, Katarzyna Zachwieja7, Ryszard Wierciński ${ }^{8}$, Hanna Kipigroch ${ }^{9}$, \\ Barbara Kołtątaj ${ }^{10}$, Marcin Tkaczyk ${ }^{1}$
}

1Nephrology Division, Department of Paediatrics and Immunology, Polish Mother's Memorial Hospital Research Institute, Lodz, Poland

2Paediatric Dialysis Department, Wroclaw, Poland

3Paediatric Dialysis Department I CZD Warsaw, Poland

4Paediatric Dialysis Department, Gdansk, Poland

5Paediatric Dialysis Department, Poznan, Poland

6Paediatric Dialysis Department, Warsaw, Poland

7Paediatric Dialysis Department, Cracow, Poland

8Paediatric Dialysis Department, Bialystok, Poland

9 Paediatric Dialysis Department, Torun, Poland

10Paediatric Dialysis Department, Lublin, Poland

Submitted: 16 April 2009

Accepted: 23 July 2009

Arch Med Sci 2010; 6, 3: 414-419

DOI: 10.5114/aoms.2010.14265

Copyright (c) 2010 Termedia \& Banach

\section{Abstract}

Introduction: Peritoneal dialysis (PD) is a preferred method of renal replacement therapy for end-stage renal disease in children. Recent advances have allowed chronic PD to be provided to children of all ages and sizes.

Material and methods: The study was designed as a national (10 dialysis centres), multicentre retrospective analysis of the medical history of 33 children who started chronic peritoneal dialysis in their infancy between 1993 and 2005, with a follow-up period of at least 24 months.

Results: The nutritional status of the infants was unsatisfactory. The mean SDS of body weight at the start was -2.0 , at 1 year of age -1.7 . Only $40 \%$ of infants were adequately nourished at 1 year of age. Long-term follow-up analysis showed that 12 children received a kidney transplant, 13 were still on dialysis (4 changed method) and 6 died (mortality rate in the first year of life of $9 \%$ ). In 2 children we observed an improvement of renal function. We observed a relatively high (1/8.8 patient-months) peritonitis rate in the analysed children when compared to $1: 22$ patient-months in all children undergoing PD in Poland.

Conclusions: The results of our survey have shown that the management of dialysed infants is still a challenge for the medical team and families, but longterm results of the therapy are encouraging.

Key words: infant, chronic dialysis, peritoneal dialysis, outcome, children.

\section{Introduction}

Peritoneal dialysis (PD) is a method of choice for renal replacement therapy for end-stage renal disease (ESRD) in children. Advanced dialysis technology has allowed chronic PD to be provided to children of all ages and sizes. Among them, special attention should be given to infants, in whom excessive mortality, infections and poor growth remain the major medical problems [1-7].

Infants require a multidisciplinary approach, intensified nutrition, and adequate control of uraemia focused on appropriate physical, neurological
Corresponding author:

Anna Jander, MD

Nephrology Division,

Department of Paediatrics and Immunology

Polish Mother's Memorial Hospital Research Institute 281/28 Rzgowska Str. 93-338 Lodz, Poland Phone: +48422712003 Fax: +48 422712015

E-mail: ajander@wp.pl 
and social development [1, 2, 8, 9]. Continuous peritoneal dialysis (CPD), introduced in children in the early 1970s, has been widely applied in the childhood population for the last 30 years [10]. In Poland, children have been offered peritoneal dialysis since the late 1970s. Nowadays, the population of dialysed children comprises about 170 subjects, in whom over $70 \%$ are dialysed peritoneally [11]. Despite this, there have been only scarce data published on the long-term outcome, survival and nutrition in infants treated with PD, and analysed groups were very small $[4,7,10,12]$. In our opinion, exchange of experience between investigators and clinicians dealing with PD in children should result in an improvement in the care of the dialysis patients. Therefore, the aim of the study was to analyse chronic PD in infancy, accompanied by further evaluation of long-term follow-up of 24 months.

\section{Material and methods}

\section{Study design}

The study was designed as a retrospective analysis of the medical history of children who started chronic peritoneal dialysis in their infancy (below 1 years of life) between 1993 and 2005 with a follow-up period of at least 24 months. The data were acquired by completion of a questionnaire addressed to medical staff of all paediatric peritoneal dialysis units in Poland (10 centres - the whole population of dialysed children in Poland). The response rate was $100 \%$. The form included questions concerning the origin of the CKD, clinical status (nutrition - body weight, psychomotor development - assessed by treating physician) and basic laboratory measures (kidney function, calcium-phosphate balance, parathormone, haemoglobin concentration). The data were collected anonymously. The form was constructed so as to contain all the data in one sheet. The respondents additionally reported the 2-year outcome as separate information.

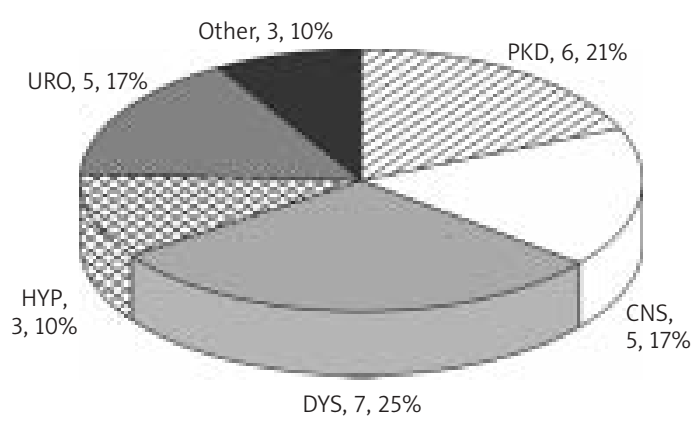

Figure 1. Primary kidney disease in the study group PKD - polycystic kidney disease, CNS - congenital nephrotic syndrome, DYS - dysplastic kidneys, HYP - hypoplastic kidneys, URO - uropathies
The data were gathered at the beginning of PD and at 3, 6, 9 and 12 months of life. Episodes of exit site infection (ESI) and peritonitis were counted and related to the duration of PD. These entities were diagnosed by commonly accepted guidelines $[13,14]$. Factors responsible for and the number of Tenckhoff catheter reimplantations were assessed. Based on anthropometric measures and available normal values of the Polish population, standard deviation scores (SDS) were calculated from the formula (observed value $-50^{\text {th }}$ percentile value) $/(0.5$ $\times$ (value of 50 percentile - value of $3^{\text {rd }}$ percentile) $)$ [15]. Additional information on the overall outcome (transplantation, change in renal replacement therapy, renal function improvement, death) was assessed in a long-term observation at the age of 3 years.

\section{Statistical analysis}

Statistica 6.0 PL software (StatSoft Inc, Tulsa, USA) was used for statistical analysis. The distribution of the data was checked by the Kolmogorov-Smirnov one sample test for normality. Mann-Whitney two-sample rank test or KruskalWallis ANOVA was used for between-group statistical analysis. Spearman rank correlation coefficient was calculated to assess relations between variables. Values of $p$ of less than 0.05 were considered significant. All non-normally distributed variables are presented as median and $25-75 \%$ interquartile range.

\section{Results}

The data of 33 infants (26 male, 7 female) from the participating centres were gathered and analysed. The mean age was $4.5 \pm 3.5$ months (range 0-11 $\mathrm{m}$ ), and the mean body weight $5.4 \pm 2.5 \mathrm{~kg}$ (range 2.5-10.0 kg) at the start of dialysis. Fifteen of them started PD before 3 months, 9 at 3-6 months and 9 over 6 months of life. Mean time of dialysis under 1 years of life was $6.4 \pm 3.9$ months, adding up to 210 peritoneal dialysis months. Continuous

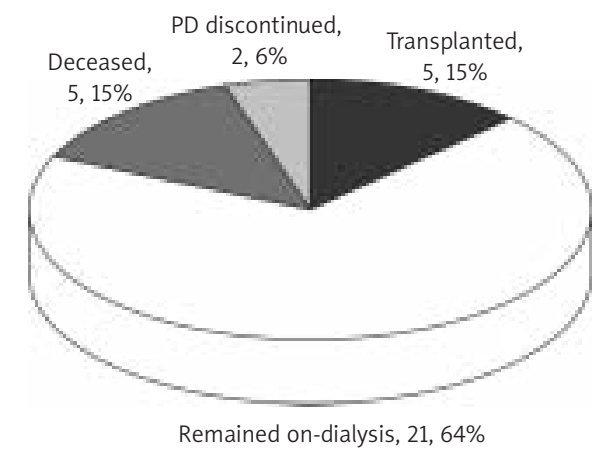

Figure 2. Three-year follow-up of children who started PD in infancy 
A. Jander, I. Makulska, J. Latoszyńska, H. Boguszewska-Bączkowska, I. Bałasz-Chmielewska, I. Zagożdżon, I. Załuska-Leśniewska, E. Stefaniak, B. Leszczyńska, K. Zachwieja, R. Wierciński, H. Kipigroch, B. Kołłątaj, M. Tkaczyk

Table I. Selected biochemical data in the study group at the start of PD. Data are presented as median value and $25-75 \%$ interquartile range

\begin{tabular}{|ll|}
\hline & Initiation of PD \\
\hline Number of patients & 33 \\
\hline Serum creatinine $[\mu \mathrm{mol} / \mathrm{l}]$ & $310(278-395)$ \\
\hline Haemoglobin concentration $[\mathrm{g} / \mathrm{l}]$ & $100(90-112)$ \\
\hline Serum calcium $[\mathrm{mmol} / \mathrm{l}]$ & $2.2(1.9-2.4)$ \\
\hline Serum phosphate $[\mathrm{mmol} / \mathrm{l}]$ & $2.3(1.7-3.5)$ \\
\hline PTH $[\mathrm{pg} / \mathrm{ml}]$ & $309(170-614)$ \\
\hline Body weight $[\mathrm{kg}]$ & $4.7(3.0-6.9)$ \\
\hline SDS for body weight & $-2.0(-2.5--0.9)$ \\
\hline Urine output [ml/kg/day] & $48^{*}(16-65)$ \\
\hline *4 children were anuric & \\
\hline
\end{tabular}

ambulatory peritoneal dialysis (CAPD) was chosen as the first method of treatment in $73 \%$ of infants, whereas at the age of 1 years the percentage decreased to $57 \%$ due to the transfer to automated peritoneal dialysis. The most frequent kidney diseases that led to ESRD were renal dysplasia (25\%) and polycystic kidney disease (21\%) (Figure 1). In 18 patients (54\%) other co-morbid conditions were present (congenital heart disease, hypoplastic lungs, hypothyroidism, cerebral palsy, hepatitis or liver cirrhosis). Data on pregnancy or birth weight were unavailable for analysis in most patients.

At the start of PD, infants had anaemia, acidosis, hyperphosphataemia with secondary hyperparathyroidism (results presented in Table I). Twenty patients (61\%) were malnourished (below -1.65 SDS for body weight). Overall SDS for body weight was -2.0.
In the analysis undertaken according to the protocol at $3 \mathrm{~m}, 6 \mathrm{~m}, 9 \mathrm{~m}, 12 \mathrm{~m}$ of life, we observed that the haemoglobin concentration and phosphate concentration increased, and PTH concentration increased with no significant tendency or change at all time points. The infants had SDS at $3 \mathrm{~m}$ of -2.2 for body weight without further increase at 1 years $(-1.7)$. At the age of $1 \mathrm{y}$. the body weight was over -1.65 of SDS in only 12 children (40\%). KT/V data were absent in over $75 \%$ of patients. The detailed biochemical characteristics at 3, 6, 9 and 12 months of life are given in Table II.

Peritonitis (24 episodes) occurred with the frequency of 1.34 episodes/patient/years (1 per 8.8 patient-months) while ESI occurred with the frequency of 0.63 episodes/patient/years (1 per 19 patient-months). Gram positive pathogens were the major causative agents (61\%). Ten infants (30\%) required surgical hernia repairs. Three patients (9\%) died in infancy due to cardiac arrest (1), sepsis (1) and dialysis withdrawal (1). No infant was kidney transplanted below 1 year of age. Three other patients died later in childhood (due to sepsis $n=2$, abdominal catastrophe $n=1$ ), which led to overall mortality of $18.2 \%$.

Long-term follow-up analysis showed that 5 children were transplanted before 3 years (7 patients later in life), 21 were still on dialysis (1 was transferred to haemodialysis) and 2 more died (1 later in life). In 2 children dialysis was withdrawn due to kidney function improvement. For 12 children who were transplanted the mean age of surgery was 58 months, with the body weight over $12 \mathrm{~kg}$. They have been waiting for a renal graft from 24 to 104 months from the initiation of PD. Out of 22 infants (available data) neurological assessment

Table II. Selected clinical and biochemical data in the study group in the first year of life (in 3-month intervals).

Data are presented as median value and $25-75 \%$ interquartile range

\begin{tabular}{|lcccc|}
\hline & 3 months of life & 6 months of life & 9 months of life & 12 months of life \\
\hline Number of patients & 15 & 20 & 26 & 30 \\
\hline $\begin{array}{l}\text { Serum creatinine } \\
{[\mu \mathrm{mol} / \mathrm{l}]}\end{array}$ & $292(248-392)$ & $292(258-317)$ & $270(172-318)$ & $327(283-424)$ \\
\hline $\begin{array}{l}\text { Haemoglobin } \\
\text { concentration }[\mathrm{g} / \mathrm{l}]\end{array}$ & $103(96-119)$ & $109(95-120)$ & $110(93-123)$ & $109(95-118)$ \\
\hline $\begin{array}{l}\text { Serum calcium } \\
\text { [mmol/l] }\end{array}$ & $2.3(2.0-2.6)$ & $2.3(2.1-2.4)$ & $2.2(2.0-2.4)$ & $2.4(2.1-2.5)$ \\
\hline $\begin{array}{l}\text { Serum phosphate } \\
\text { [mmol/l] }\end{array}$ & $1.9(1.4-2.3)$ & $2.2(1.5-2.9)$ & $2.2(1.3-2.5)$ & $1.9(1.7-2.3)$ \\
\hline $\begin{array}{l}\text { PTH }[\text { pg/ml] } \\
\text { Body weight }[\mathrm{kg}]\end{array}$ & $412(221-393)$ & $384(127-540)$ & $214(118-513)$ & $454(152-596)$ \\
\hline $\begin{array}{l}\text { SDS for body } \\
\text { weight }\end{array}$ & $-2.0(-3.3--1.6)$ & $-1.9(-3.0--1.1)$ & $-1.9(-2.6--1.5)$ & $-1.7(-2.2--1.1)$ \\
\hline $\begin{array}{l}\text { Urine output } \\
\text { [ml/kg] }\end{array}$ & $50(50.3-60.0)$ & $48(24-64)$ & $4.7(5.7-7.6)$ & $5.0-8.6)$ \\
\hline
\end{tabular}

*10 children were anuric 
Table III. Comparison of patients who started dialysis before and after 6 months of life at the age of 1 year. Data are presented as median value and $25-75 \%$ interquartile range

\begin{tabular}{|c|c|c|c|c|}
\hline Time of PD initiation & \multicolumn{2}{|c|}{$<6$ months } & \multicolumn{2}{|c|}{$\geq 6$ months } \\
\hline \multirow[t]{2}{*}{ Number of patients } & \multicolumn{2}{|c|}{21} & \multicolumn{2}{|c|}{12} \\
\hline & Start & $12 \mathrm{~m}$ & Start & $12 \mathrm{~m}$ \\
\hline Serum creatinine $[\mu \mathrm{mol} / \mathrm{l}]$ & $\begin{array}{c}292 \\
(238-372)\end{array}$ & $\begin{array}{c}323 \\
(286-427)\end{array}$ & $\begin{array}{c}336 \\
(292-404)\end{array}$ & $\begin{array}{c}345 \\
(288-534)\end{array}$ \\
\hline Haemoglobin concentration $[\mathrm{g} / \mathrm{l}]$ & $\begin{array}{c}107 \\
(98-129)\end{array}$ & $\begin{array}{c}114 \\
(107-121)\end{array}$ & $\begin{array}{c}931 \\
(79-100)\end{array}$ & $\begin{array}{c}1001,2 \\
(91-108)\end{array}$ \\
\hline Serum calcium [mmol/l] & $\begin{array}{c}2.3 \\
(1.8-2.5)\end{array}$ & $\begin{array}{c}2.4 \\
(2.2-2.6)\end{array}$ & $\begin{array}{c}2.2 \\
(2.0-2.4)\end{array}$ & $\begin{array}{c}2.3 \\
(2.1-2.4)\end{array}$ \\
\hline Serum phosphate $[\mathrm{mmol} / \mathrm{l}]$ & $\begin{array}{c}2.6 \\
(1.5-4.5)\end{array}$ & $\begin{array}{c}2.2 \\
(1.5-2.9)\end{array}$ & $\begin{array}{c}1.8^{1} \\
(1.7-2.6)\end{array}$ & $\begin{array}{c}1.8^{1} \\
(1.7-1.8)\end{array}$ \\
\hline PTH $[\mathrm{pg} / \mathrm{ml}]$ & $\begin{array}{c}200 \\
(119-542)\end{array}$ & $\begin{array}{c}4292 \\
(165-633)\end{array}$ & $\begin{array}{c}850^{1} \\
(250-1324)\end{array}$ & $\begin{array}{c}406^{2} \\
(190-525)\end{array}$ \\
\hline Body weight [kg] & $\begin{array}{c}3.3 \\
(2.8-4.8)\end{array}$ & $\begin{array}{c}7.3 \\
(6.9-8.5)\end{array}$ & $\begin{array}{c}8.51 \\
(6.8-9.6)\end{array}$ & $\begin{array}{c}8.01 \\
(7.8-9.0)\end{array}$ \\
\hline SDS for body weight & $\begin{array}{c}-2.1 \\
(-3.1--1.4)\end{array}$ & $\begin{array}{c}-2.0 \\
(-2.4--1.3)\end{array}$ & $\begin{array}{c}-1.31 \\
(-2.2--0)\end{array}$ & $\begin{array}{c}-1.51 \\
(-1.7--0.9)\end{array}$ \\
\hline$\Delta$ SDS for body weight & - & $\begin{array}{c}-0.4 \\
(-1.1-0.5)\end{array}$ & - & $\begin{array}{c}0^{1} \\
(-0.3-0.7)\end{array}$ \\
\hline Urine output [ml/kg] & $\begin{array}{c}41 \\
(16-64)\end{array}$ & $\begin{array}{c}58 \\
(40-71)\end{array}$ & $\begin{array}{c}58 \\
(13-66)\end{array}$ & $\begin{array}{c}58 \\
(24-68)\end{array}$ \\
\hline
\end{tabular}

$\triangle S D S=S D S$ at $12 m-S D S$ at the beginning of dialysis

${ }_{1}^{1}$ significantly different when compared to children who started $P D$ before $6 m, p<0.05$, 2significantly different when compared to beginning of $P D, p<0.05$

done by the treating physician showed an adequate stage of development in 10 patients, while in 12 retardation was observed.

Based on the clinical criterion of < or $>6$ months of age at the initiation of PD, the study group was divided into two subgroups ( $n=21$ and $n=12$, respectively) (Table III). The analysis performed in this setting revealed that their initial renal function measured by serum creatinine did not differ significantly; however, children starting PD before 6 months of life had higher haemoglobin concentration both at the start and at the age of 12 months. The increase of haemoglobin during PD treatment was similar in both observed groups of infants, whereas serum calcium was at a comparable level. Patients starting PD earlier exhibited more severe hyperphosphataemia. Their PTH concentration at the beginning of dialysis was lower than in older infants, but we observed further increase, while in the latter group PTH concentration decreased during PD.

Infants from both subgroups were malnourished, but children commencing PD over 6 months of life had higher SDS for body weight (-1.3 vs. -2.1 , $p=0.003)$. We observed no improvement in this parameter when compared to the age of 1 year, and the difference observed earlier persisted. The additional survey revealed that out of 10 par- ticipating centres only 2 (9 pts) applied gastroenteral feeding in the study period as a routine treatment for children undergoing peritoneal dialysis. Peritonitis occurred significantly more frequently in patients who commenced dialysis before 6 months $(1.47$ vs. 0.9 episodes/patient/year, $1 / 8$ vs. $1 / 13 \mathrm{pm}, p=0.021$ ).

Similarly, the frequency of Tenckhoff catheter reimplantation procedures was increased in these infants (0.56 vs. 0.31 episodes/patient/year, $p=0.041)$. There was no significant difference in ESI rate (0.56 vs. 0.29 episodes/patient/year, 1/21 vs. $1 / 13 \mathrm{pm})$.

When the transplanted children group $(n=12)$ was analysed in detail, we found that they had lower concentration of haemoglobin (105 vs. $118 \mathrm{~g} / \mathrm{l}$ ) and higher body weight ( $8.5 \mathrm{vs} .7 .0 \mathrm{~kg}$ ) at the $12^{\text {th }}$ month of life. Seven of the transplanted children started dialysis after 6 months (58\%) whereas $5(42 \%)$ started earlier. There was a significant difference in the transplantation rate between those who started PD before and after 6 months of life ( $24 \%$ vs. $58 \%, p=0.042$ ).

Additional analysis revealed that the subjects who died during dialysis treatment ( 6 children) had significantly lower urine output when compared to those who survived. 
A. Jander, I. Makulska, J. Latoszyńska, H. Boguszewska-Bączkowska, I. Bałasz-Chmielewska, I. Zagożdżon, I. Załuska-Leśniewska, E. Stefaniak, B. Leszczyńska, K. Zachwieja, R. Wierciński, H. Kipigroch, B. Kołłątaj, M. Tkaczyk

\section{Discussion}

Although the results of peritoneal dialysis therapy in small children have been improving in recent years, chronic PD in infants still continues to present an extreme challenge for many clinicians $[2,5]$. High mortality rate, frequent infections, technical problems, and poor growth are very common in this group of patients $[1-3,8,9,16]$. The percentage of children who started PD under 2 years of age remains low $(13 . \%$ in the 2001 NAPRTC report, $12.5 \%$ according to the Italian registry) [16-18]. In Finland there is a higher proportion of infants among all dialysed children (35\%) than in other countries, mainly on account of the congenital nephrotic syndrome of the Finnish type [19]. In the Polish registry (2000-2004) children who started PD in infancy constituted below $10 \%$ of children requiring renal replacement therapy. In earlier studies, infants made up only about $1-2 \%$ of the paediatric ESRD population [9].

In our study, most children who started PD in infancy survived up to $12 \mathrm{~m}$ of life, but 3 children died during the study period. The mortality rate was $9 \%$, which is comparable to the results reported by other authors $[7,9,10]$, but lower than in the studies of Ellis et al. and Ledermann et al. [4, 20]. The mortality rate in infants starting dialysis is as many as 4 times higher than that of children beyond infancy [21]. Most deaths occur in the first year of life. A 1-year survival of $85 \%$ was found in this population by NAPRTC and in the UK, which is lower than the $95 \%$ reported in children starting dialysis after infancy $[6,18]$. It should be noted that in the most difficult age group to treat with dialysis, i.e. those under 5 years, mortality has continued to fall in Europe. The 2-year survival in children on dialysis aged $0-4$ years increased from $71.3 \%$ in $1980-1984$ to $87 \%$ in $1995-2000$ [22].

Complications related to the peritoneal catheter, such as peritonitis, exit site infection (ESI), tunnel infection, pericatheter leakage or mechanical dysfunction, are very common in infants undergoing PD $[1,8,19,23]$ and remain troublesome $[1,2]$. In our study, 10 infants (30\%) needed hernia repairs. Laakonnen et al. reported 23 infants on PD in Finland; among them 13 (56\%) underwent operations due to inguinal or umbilical hernias or hydrocele [10]. Lederman et al. (12) documented hernias in 15 infants (75\%) whereas Hölttä et al. (9) observed them in $92 \%$ of children under age 5 years $[7,24]$. In our study, 7 patients $(21 \%)$ needed catheter exchange, but the frequency of peritoneal catheter reimplantation was greater in infants who started PD under 6 months of age (revision ratio 0.56 vs. $0.31, p<0.05)$. Laakonnen et al. described 10 patients (43\%) who needed a catheter exchange at least once, with a revision ratio of 0.65 [10]. On the other hand, Lederman et al. reported 20 infants on PD, among whom in 10 (50\%) the catheter was replaced once and in 2 (10\%) twice [7]. Consequently, it seems that catheter-related technical problems remain very common in children who started PD under one year of age.

We observed a relatively high (1/8.8 ptm) peritonitis rate when compared to $1: 22 \mathrm{ptm}$ in all children undergoing PD in Poland [25]. This was confirmed by other authors in infants and small children - range $1 / 7.5$ to $1 / 14.5 \mathrm{ptm}[7,10,18]$. The exit site infection rate (1/19 ptm) was also higher than in the general PD population in Poland (1/25-30 ptm). Kaluzynska and colleagues reported an ESI rate of 1/9.6 ptm in children under the age of 5 years when compared to older patients (1/26.5 pmt) [26]. The importance of ESI prevention is high because ESI can lead to tunnel infections and peritonitis [14]. Gram-positive bacteria were the most common cause of peritonitis in our patients (61\%), similarly to other recent and earlier reports $[7,10,13,14,25]$.

The concept that chronic renal failure occurring in the first 2 years of life may have a long-standing adverse effect on height prognosis is well known. Growth at this time is principally dependent on nutrition $[8,9,20,27]$.

The results of our analysis in terms of growth and nutrition are disappointing, and significantly worse than those reported by Ledermann et al. and Laakkonen et al. In our group, the mean SDS of body weight at the start was -2.0 , at 1 year of age $-1.7[7,10,20]$. Only $40 \%$ of infants analysed were adequately nourished at 1 year of age. Children commencing PD over 6 months of life had higher SDS for body weight (-1.3 vs. 2.1), and the observed differences persisted to the age of 1 year. Only two centres (of 10 participating) applied gastroenteral feeding as a routine treatment. Parents' disagreement, technical and economic problems or reluctance of the medical staff could be responsible for this situation. It should be strongly emphasised that the commencement of careful nutritional support early in the course of the dialysis treatment may not only improve growth but also limit mortality in children undergoing PD [27, 28].

There is a small number of reports which analyse long-term emotional and developmental outcome in children starting PD in infancy. Lederman et al. reported good results. Warady et al. found that of 28 survivors of 34 infants who began dialysis before 3 months of age, only 1 was significantly delayed $[29,30]$. In our study, $55 \%$ of children were delayed. In the observed infants, developmental delay was attributed mainly to perinatal asphyxia or genetic disease.

To summarize, the results of our multicentre survey are comparable to data presented in other countries with regard to most of the analysed 
parameters. However, there is a strong need to maintain adequate nutritional support to preserve normal growth and development in PD infants. The study revealed that the management of infants with ESRD remains a challenge for the medical team and families, but overall results are encouraging.

\section{Acknowledgments}

The study was carried out under the auspices of the Polish Society for Paediatric Nephrology. The authors would like to thank prof. prof. Danuta Zwolińska, Ryszard Grenda, Jacek A. Pietrzyk, Maria Roszkowska-Blaim, Jacek Zachwieja, Maria Zajączkowska, Walentyna Zoch-Zwierz, Aleksandra Żurowska, dr Roman Stankiewicz, and Maria Szczepańska for cooperation in conducting the study and Ms Anna Kamińska for her secretarial assistance.

\section{References}

1. Bunchman TE. Chronic dialysis in the infant less than 1 year of age. Pediatr Nephrol 1999; 9: 18-23.

2. Bunchman TE. Infant dialysis: the future is now. J Pediatr 2000; 136: 1-2.

3. Carey WA, Talley LI, Sehring SA, Jaskula JM, MathiasRS. Outcomes of dialysis initiated during the neonatal period for treatment of end-stage renal disease: A North American Pediatric Renal Trials and Collaborative Studies Special Analysis. Pediatrics 2007; 11: 468-73.

4. Ellis EN, Person D, Champion IB, Wood EG. Outcome of infants on chronic peritoneal dialysis. Adv Perit Dial 1995; 11: 266-72.

5. Flynn JT, Warady BA. Peritoneal dialysis in children: challenges for the new millennium. Adv Ren Replace Ther 2000; 7: 374-54.

6. Kari JA, Gonzales C, Ledermann SE. Outcome and growth of infants with severe chronic failure. Kidney Int 2000; 57: 1523-8.

7. Lederman S, Scanes ME, Fernando ON, Duffy PG, Madden SJ, Trompeter RS. Long-term outcome of peritoneal dialysis in infants. J Pediatr 2000; 136: 24-9.

8. Rees L. Long-term peritoneal dialysis in infants. Perit Dial Int 2007; 27: 180-4.

9. Rees L. Management of the infant with end-stage renal failure. Nephrol Dial Transplant 2002; 17: 1564-7.

10. Laakkonen H, Hölttä T, Lönnqvist T, Holmberg C, Rönnholm KA. Peritoneal dialysis in children under two years of age. Nephrol Dial Transplant 2008; 23: 1747-53.

11. Grenda R, Rutkowski B, Rubik J. Dializoterapia otrzewnowa u dzieci w Polsce w 2003 r. In: Puka J (ed.). Raport o stanie leczenia nerkozastępczego w Polsce [Polish]. MZiOS PTN, Gdansk 2004; 48-52.

12. Feinstein S, Rinat C, Becker-Cohen R, Ben-Shalom E, Schwartz SB, Frishberg Y. The outcome of chronic dialysis in infants and toddlers-advantages and drawbacks of haemodialysis. Nephrol Dial Transplant 2007; 23: 1336-45.

13. Warady BA, Feneberg R, Verrina E, et al. Peritonitis in children who receive long-term peritoneal dialysis: a prospective evaluation of therapeutic guidelines. J Am Soc Nephrol 2007; 18: 2172-9.
14. Furth SL, Donaldson LA, Sullivan EK, Watkins SL Peritoneal dialysis catheter infections in children: a report of the North American Pediatric Renal Transplant Cooperative Study. Pediatr Nephrol 2000; 15: 179-85.

15. Palczewska I, Niedzwiecka Z. Siatki centylowe do oceny rozwoju somatycznego dzieci i młodzieży [Polish]. IMD, Warszawa 1999.

16. Wood EG, Hand M, Briscoe DM, et al. North American Pediatric Renal Transplant Cooperative Study (2001) Risk factors for mortality in infants and young children on dialysis. Am J Kidney Dis 2002; 37: 573-9.

17. Verrina E, Edefonti A, Gianoglio B, et al. A multicenter experience on patient and technique survival in children on chronic peritoneal dialysis. Pediatr Nephrol 2004; 19: 82-90.

18. Neu AM, Ho PL, Mc Donald RA, Warady BA. Chronic dialysis in children and adolescents. The 2001 NAPRTCS Annual Report. Pediatr Nephrol 2002; 17: 656-63.

19. Rönnholm KA, Holmberg C. Peritoneal dialysis in infants. Pediatr Nephrol 2006; 21: 751-6.

20. Ledermann SE, Spitz L, Rees L, Moloney J, Trompeter RS. Gastrostomy feeding in infants and children on peritoneal dialysis. Pediatr Nephrol 2002; 17: 246-50.

21. Shroff R, Rees L, Trompeter R, Hutchinson C, Ledermann S. Long-term outcome of chronic dialysis in children. Pediatr Nephrol 2006; 21: 257-64.

22. Van der Heijden BJ, van Dijk PC, Verrier-Jones K, Jager KJ, Briggs JD. Renal replacement therapy in children: data from 12 registries in Europe. Pediatr Nephrol 2004; 19: 213-21.

23. Aksu N, Yavascan O, Anil M, Kara OD, Erdokan H, Bal A. A ten-year single centre experience in children on chronic peritoneal dialysis-significance of percutaneous placement of peritoneal dialysis catheters. Nephrol Dial Transplant 2007; 22: 2045-51.

24. Höittä TM, Rönnholm KA, Jalanko H, Ala-Houhala M, Antikainen M, Holmberg C. Peritoneal dialysis in children under 5 years of age. Perit Dial Int 1997; 17: 573-80.

25. Zurowska A, Zagozdzon I, Balasz I, et al. Peritonitis in 203 children treated with peritoneal dialysis In Poland during 2000-2003. Adv Clin Exp Med 2008; 17: 167-72.

26. Kaluzynska A, Czupryniak A, Jander A, Nowicki M. Peritoneal dialysis complications in chronic and acute renal insufficiency. Pol Merkuriusz Lek 2002; 70: 288-90.

27. Rees L, Shaw V. Nutrition in children with CRF and on dialysis. Pediatr Nephrol 2007; 22: 1689-702.

28. Brem A, Lambert C, Hill C, Kitsen J, Shemin D. Prevalence of protein malnutrition in children maintained on peritoneal dialysis. Pediatr Nephrol 2002; 17: 527-30.

29. Warady BA, Belden B, Kohaut E. Neurodevelopmental outcome of children initiating peritoneal dialysis in early infancy. Pediatr Nephrol 1999; 13: 759-64.

30. Madden SJ, Ledermann SE, Guerrer-Blanco M. Cognitive and psychosocial outcome of infants dialysed in infancy. Child Care Health Dev 2003; 29: 55-9. 